\title{
Pengukuran Kualitas “SIWESI" IBSI Education Berdasarkan Sudut Pandang Teknis Sistem
}

Sindi Dwi Putri S

Sistem Informasi, Fakultas Teknik, Universitas Nahdlatul Ulama Surabaya Jalan Raya Jemursari 57-58, Jemur Wonosari, Wonocolo-Surabaya 60237

\begin{abstract}
Abstrak
Sistem informasi suatu organisasi atau perusahaan berguna untuk mengelola data untuk menghasilkan suatu informasi yang berguna dan efektif yang mendukung kegiatan dan seluruh tingkat manajemen yang menggunakan. IBSI Education salah satunya merupakan Lembaga Bimbingan Belajar yang menggunakan "SiWeSi" untuk mendukung administrasi, melihat jadwal, melihat perkembangan murid, dan sebagainya. Penelitian ini menggunakan model kualitas McCall kareana mtode ini memenuhi banyak komponen penilaian dan melihat kualitas dari sudut pandang pengguna. Model kualitas tersebut yang digunakan untuk mengukur kualitas SIWESI ditentukan dari hasil studi literatur.
\end{abstract}

\begin{abstract}
The information system of an organization or company is useful for managing data to produce useful and effective information that supports activities and all levels of management that use. IBSI Education is one of them is a Tutoring Institution that uses "SiWeSi" to support administration, view schedules, see student development, and so on. This study uses the McCall quality model because this method fulfills many assessment components and looks at quality from the user's perspective. The quality model used to measure the quality of SIWESI is determined from the results of the literature study.
\end{abstract}

\section{PENDAHULUAN}

Sistem informasi didalam suatu organisasi atau perusahaan berguna untuk mengelola data untuk menghasilkan suatu informasi yang berguna dan efektif yang mendukung kegiatan dan seluruh tingkat manajemen yang menggunakan. IBSI Education merupakan lembaga bimbingan belajar yang menawarkan les privat, les group, dan les kelas. Lembaga bimbingan belajar ini berdiri sekitar tahun 2014 dan pada saat itu belum terdapat sebuah sistem untuk mengontrol para tentor dan pihak Lembaga bimbingan belajar sendiri. 
IBSI Education salah satunya merupakan Lembaga Bimbingan Belajar yang menggunakan "SiWeSi" untuk mendukung administrasi, melihat jadwal, melihat perkembangan murid, dan sebagainya. Terlebih lagi "SiWeSi" ini sendiri akan digunakan untuk menjalankan proses bisnis di lembaga bimbingan belajar maka perlu dilakukan sebuah pengukuran kualitas. Yang mana kualitas yang akan diukur dilihat dari sudut pandang teknis dan pengguna sistem. Artikel ilimiah ini bermaksud untuk mengetahui tingkat kualitas "SiWeSi” IBSI Education dengan kekurangan dan rekomendasi perbaikan.

\section{METODOLOGI PENELITIAN}

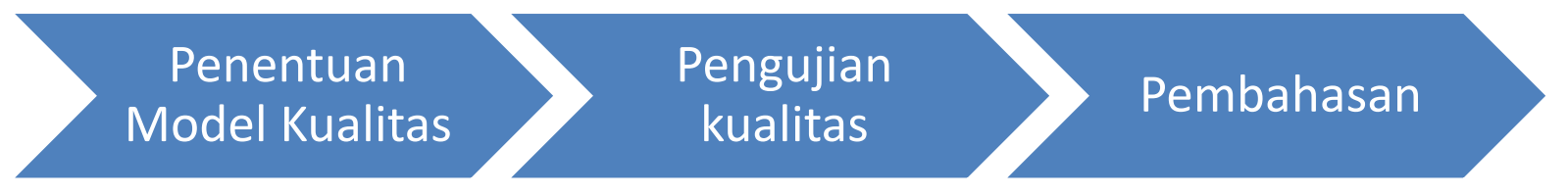

Gambar 1. Metodologi Penelitian 1

Model kualitas adalah kualitas karakteristik dan relasi diantara elemen - elemennya. Metode kualitas menentukan kebutuhan kualitas dan evaluasi kualitas. Perbandingan dari beberapa model kualitas seperti McCall, Boehm, dromey, FURPS, BBN, Star, dan ISO 9126. Hasilnya menunjukan bahwa model kualitas McCall memenuhi banyak komponen penilaian dan melihat kualitas dari sudut pandang pengguna. Model kualitas tersebut yang digunakan untuk mengukur kualitas SIWESI ditentukan dari hasil studi literatur.

Setelah menentukan model kualitas kemudian tahapan pengujian kualitas, pengukuran dilakukan dengan mengukur pada masing - masing sudut pandang. Pada tahapan ini juga ditentukan pihak yang terkait dengan pengujian.

\section{HASIL DAN ANALISIS}

\subsection{Pengujian Kualitas dan Pembahasan}

Pelaksanaan pengujian dirinci dalam pengujian pada perspektif teknis sistem oleh pengguna. Pengujian ini dilihat dari beberapa faktor yang diuji menggukana bantuan tool seperti Page Speed. 


\section{Efisiensi}

Untuk menguji faktor efisiensi dilakukan menggunakan alat bantu page speed online. Alat bantu ini merupakan fitur Google yang memberikan fasilitas untuk menganalisa kinerja kecepatan halaman website dengan score. Hasil pengujian efesiensi disajikan pada gambar 1 dan gambar 2.

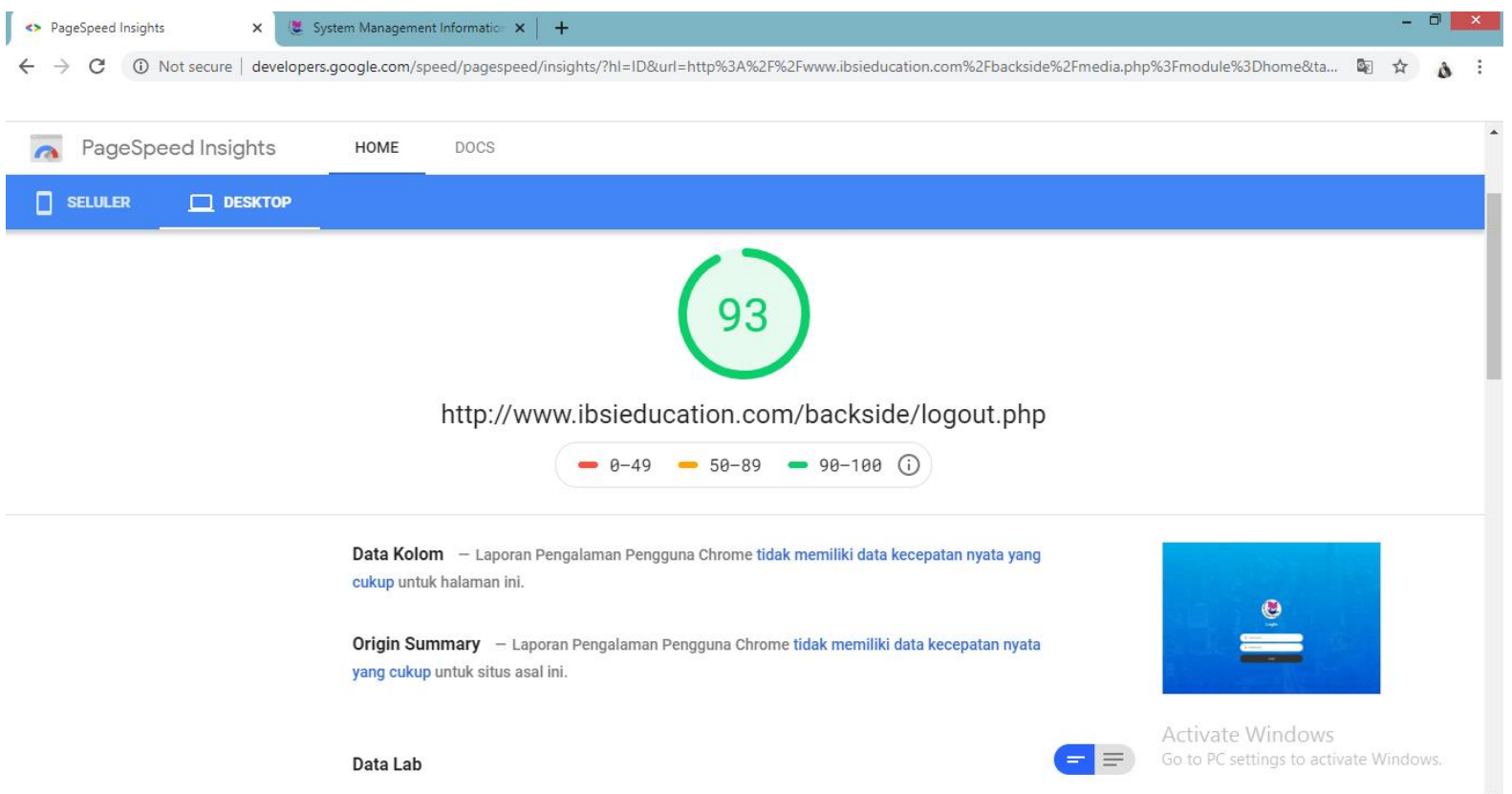

\section{Gambar 1. Hasil Pengujian Page Speed}

Berdasarkan hasil pengujian pada Gambar 1, diketahui bahwa kecepatan

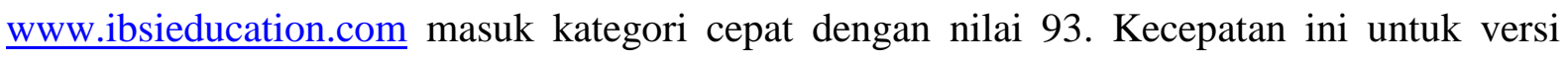
desktop. Waktu yang dibutuhkan oleh SIWESI untuk menampilkan konten utama halaman dan menjadi interaktif sepenuhnya adalah 0,7 detik. Sementara indeks kecepatan SIWESI, yakni seberapa cepat konten halaman terlihat berisi lengkap sebesar 1,1 detik. Selain kecepatan untuk menampilkan informasi, page speed online juga memberikan informasi tentang potensi penundaan input pertama yang mungkin dialami oleh pengguna, yakni sebesar 20 md. Selain hasil dari versi desktop, page speed online juga dapat menunjukkan kinerja kecepatan pada versi seluler. Sesuai Gambar 2, SIWESI diketahui masuk kategori agak sedikit lambat dengan nilai 73. Nilai ini sedikit kurang baik dari versi desktop. 


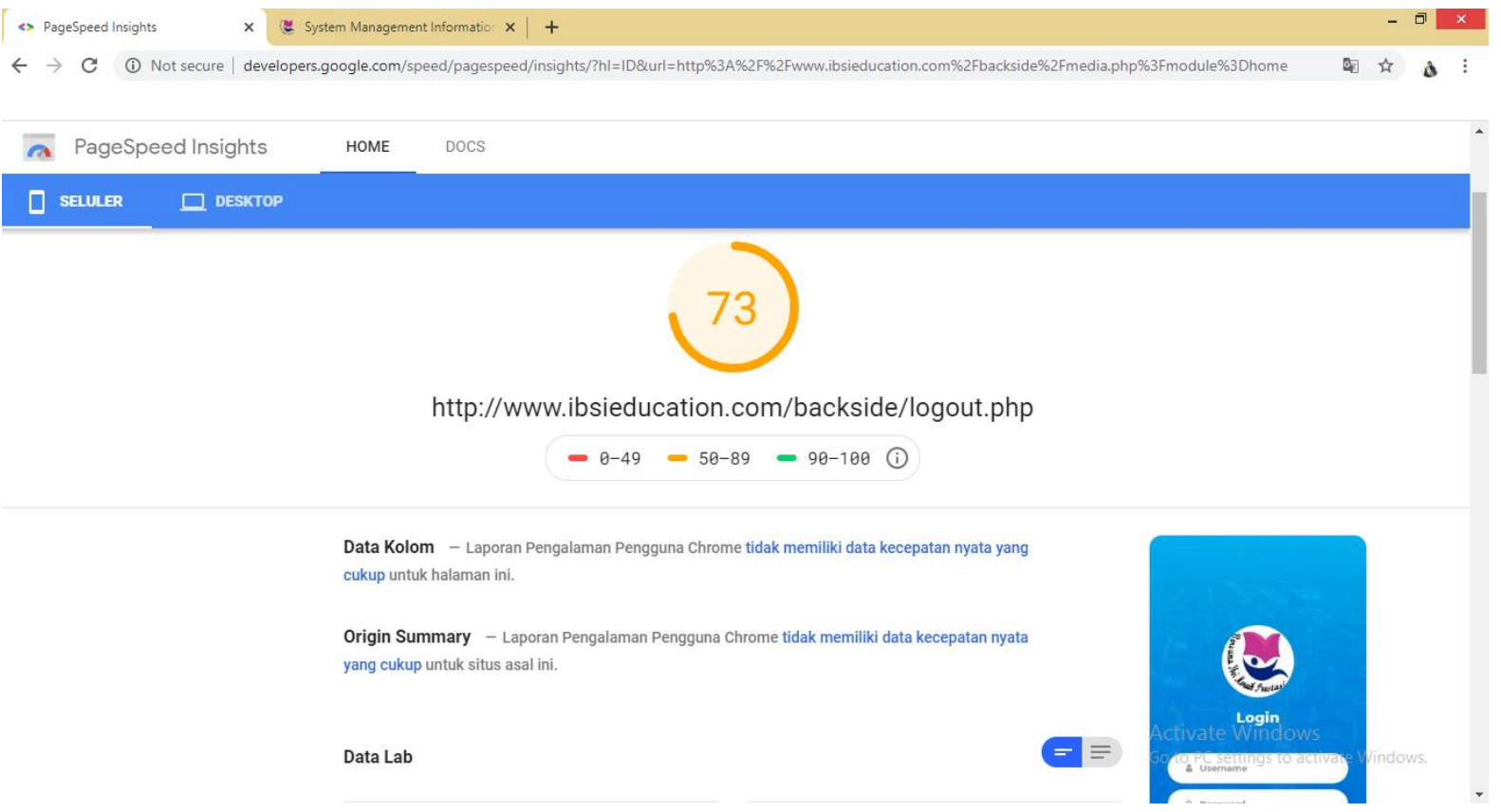

\section{Gambar 2. Hasil Pengujian Page Speed}

2. Portabilitas

Untuk pengujian pada faktor portabilitas menggunakan alat bantu perangkat desktop dan mobile dengan beberapa browser. Rincian pengujian tersaji pada Tabel dibawah ini.

\begin{tabular}{|l|c|c|}
\hline Perangkat & Laptop & Smartphone \\
\hline Browser & & \\
\hline Google Chrome & $\mathrm{V}$ & $\mathrm{V}$ \\
\hline Mozilla Firefox & $\mathrm{V}$ & $\mathrm{V}$ \\
\hline
\end{tabular}

Tabel 1 Tabel Rincian Pengujian Faktor Portabilitas

Hasil ini juga terkait pada tempat akses, Fungsionalitas SIWESI sama. Hanya saja untuk proses percetakan, karena perbedaan pengaturan pada browser Mozilla dan Google Chrome, akses lebih mudah pada browser Google Chrome. Akan tetapi untuk fungsional percetakan sama-sama dapat dilakukan.

\section{KESIMPULAN}

Berdasarkan hasil pengukuran kualitas dilihat perspektif teknis sistem oleh pengguna diperoleh kesimpulan sebagai berikut : 
Secara teknis, kualitas SIWESI adalah baik dengan rincian sebagai berikut : a. Dari 5 menu, ada 1 menu yang tidak sepenuhnya dibutuhkan, honor tentor kemarin yang mana menu itu hanya digunakan melihat jumlah honor bulan kemarin.

b. Efisiensi SIWESI cepat dengan nilai 93 untuk desktop dan agak sedikit lambat 73 untuk seluler.

\section{DAFTAR PUSTAKA}

Endang Sulistiyani, A. S. K., Oktober 2019. Pengukuran Kualitas SIM Akademik UNUSA Berdasarkan Persepsi Teknis, Pengguna,dan Penyedia Layanan. Jurnal Sistem Informasi, Volume VOL.11, NO.2.

Khairullah, B. S. H. A. F., September 2017 . PENGUKURAN KUALITAS SISTEM INFORMASI INVENTARIS ASET UNIVERSITAS MUHAMMADIYAH BENGKULU MENGGUNAKAN METODE MCCALL. Jurnal Informasi Interaktif, Volume Vol. 2 No. 2. 